Abstracta Iranica Abstracta Iranica

Revue bibliographique pour le domaine irano-aryen

Volume 28 | 2007

Comptes rendus des publications de 2005

\title{
« La cérémonie du henné en Iran central : le chant des femmes ». Cahiers de musiques traditionnelles: entre femmes. $\mathrm{n}^{\circ \circ} 18,2005$, pp. 67-78.
}

\section{Sāsān Fāțemī}

\section{(2) OpenEdition}

1 Journals

\section{Édition électronique}

URL : http://journals.openedition.org/abstractairanica/7852

DOI : 10.4000/abstractairanica.7852

ISSN : 1961-960X

Éditeur :

CNRS (UMR 7528 Mondes iraniens et indiens), Éditions de l'IFRI

\section{Édition imprimée}

Date de publication : 15 mai 2007

ISSN : 0240-8910

\section{Référence électronique}

Sāsān Fātemī, « " La cérémonie du henné en Iran central : le chant des femmes ». Cahiers de musiques traditionnelles : entre femmes. $n^{\circ} 18,2005$, pp. 67-78. », Abstracta Iranica [En ligne], Volume 28 | 2007, document 520, mis en ligne le 18 septembre 2007, consulté le 25 septembre 2020. URL : http:// journals.openedition.org/abstractairanica/7852 ; DOI : https://doi.org/10.4000/abstractairanica.7852

Ce document a été généré automatiquement le 25 septembre 2020.

Tous droits réservés 


\title{
« La cérémonie du henné en Iran
} central : le chant des femmes ». Cahiers de musiques traditionnelles: entre femmes. $\mathrm{n}^{\circ 0} 18,2005, \mathrm{pp} .67-78$.

\author{
Sāsān Fāțemī
}

Un article descriptif sur la cérémonie du henēā-bandān ou « teinture au henné » où l'A., se limitant plutôt aux régions centrales de l'Iran, donne une explication assez succincte du rôle prédominant des femmes, aussi bien sur le plan cérémonial que sur le plan musical, dans cette phase de la cérémonie du mariage. Elle présente également la partie du répertoire musical exécuté à cette occasion par les femmes non-professionnelles.

\section{INDEX}

Thèmes : 17.1.Musique

\section{AUTEURS}

SĀSĀN FĀṬEMĪ

Université de Téhéran 